\title{
Whole cell-based catalyst for enzymatic production of the osmolyte 2-O-a-glucosylglycerol
}

Katharina N. Schwaiger ${ }^{1,2}$, Monika Cserjan-Puschmann ${ }^{1,3}$, Gerald Striedner ${ }^{1,3}$ and Bernd Nidetzky , $^{1 *}$ (D)

\begin{abstract}
Background: Glucosylglycerol (2-O-a-D-glucosyl-sn-glycerol; GG) is a natural osmolyte from bacteria and plants. It has promising applications as cosmetic and food-and-feed ingredient. Due to its natural scarcity, GG must be prepared through dedicated synthesis, and an industrial bioprocess for GG production has been implemented. This process uses sucrose phosphorylase (SucP)-catalyzed glycosylation of glycerol from sucrose, applying the isolated enzyme in immobilized form. A whole cell-based enzyme formulation might constitute an advanced catalyst for GG production. Here, recombinant production in Escherichia coli BL21(DE3) was compared systematically for the SucPs from Leuconostoc mesenteroides (LmSucP) and Bifidobacterium adolescentis (BaSucP) with the purpose of whole cell catalyst development.
\end{abstract}

Results: Expression from pQE30 and pET21 plasmids in E. coli BL21(DE3) gave recombinant protein at 40-50\% share of total intracellular protein, with the monomeric LmSucP mostly soluble $(\geq 80 \%)$ and the homodimeric BaSucP more prominently insoluble ( 40\%). The cell lysate specific activity of LmSucP was 2.8-fold (pET21; $70 \pm 24 \mathrm{U} / \mathrm{mg} ; N=5$ ) and 1.4-fold (pQE30; $54 \pm 9 \mathrm{U} / \mathrm{mg}, N=5$ ) higher than that of BaSuCP. Synthesis reactions revealed LmSucP was more regio-selective for glycerol glycosylation ( 88\%; position O2 compared to O1) than BaSucP ( 66\%), thus identifying LmSucP as the enzyme of choice for GG production. Fed-batch bioreactor cultivations at controlled low specific growth rate $\left(\mu=0.05 \mathrm{~h}^{-1} ; 28^{\circ} \mathrm{C}\right)$ for LmSucP production (pET21) yielded $\sim 40 \mathrm{~g}$ cell dry mass (CDM)/L with an activity of $2.0 \times 10^{4} \mathrm{U} / \mathrm{g} C D M$, corresponding to $39 \mathrm{U} / \mathrm{mg}$ protein. The same production from the $\mathrm{pQE} 30$ plasmid gave a lower yield of $6.5 \times 10^{3} \mathrm{U} / \mathrm{g} C D M$, equivalent to $13 \mathrm{U} / \mathrm{mg}$. A single freeze-thaw cycle exposed $\sim 70 \%$ of the intracellular enzyme activity for $\mathrm{GG}$ production ( $65 \mathrm{~g} / \mathrm{L}, \sim 90 \%$ yield from sucrose), without releasing it from the cells during the reaction.

Conclusions: Compared to BaSucP, LmSucP is preferred for regio-selective GG production. Expression from pET21 and pQE30 plasmids enables high-yield bioreactor production of the enzyme as a whole cell catalyst. The freezethaw treated cells represent a highly active, solid formulation of the LmSucP for practical synthesis.

Keywords: 2-O-a-glucosylglycerol, Sucrose phosphorylase, Whole-cell biotransformation, High-yield protein expression, Fed-batch fermentation

*Correspondence: bernd.nidetzky@tugraz.at

${ }^{2}$ Institute of Biotechnology and Biochemical Engineering, Graz University of Technology, NAWI Graz, Petersgasse 12,8010 Graz, Austria

Full list of author information is available at the end of the article

\section{Background}

The 2-O- $\alpha$-D-glucopyranosyl-sn-glycerol (GG; Fig. 1a) is a natural compatible solute [1]. GG is prominently found in cyanobacteria that use it to counter the osmolality of saline environments [2,3]. GG is additionally found in the resurrection plant Myrothamnus flabellifolia [4]. This

(c) The Author(s) 2021. This article is licensed under a Creative Commons Attribution 4.0 International License, which permits use, sharing, adaptation, distribution and reproduction in any medium or format, as long as you give appropriate credit to the original author(s) and the source, provide a link to the Creative Commons licence, and indicate if changes were made. The images or other third party material in this article are included in the article's Creative Commons licence, unless indicated otherwise in a credit line to the material. If material is not included in the article's Creative Commons licence and your intended use is not permitted by statutory regulation or exceeds the permitted use, you will need to obtain permission directly from the copyright holder. To view a copy of this licence, visit http://creativeco mmons.org/licenses/by/4.0/. The Creative Commons Public Domain Dedication waiver (http://creativecommons.org/publicdomain/ zero/1.0/) applies to the data made available in this article, unless otherwise stated in a credit line to the data. 


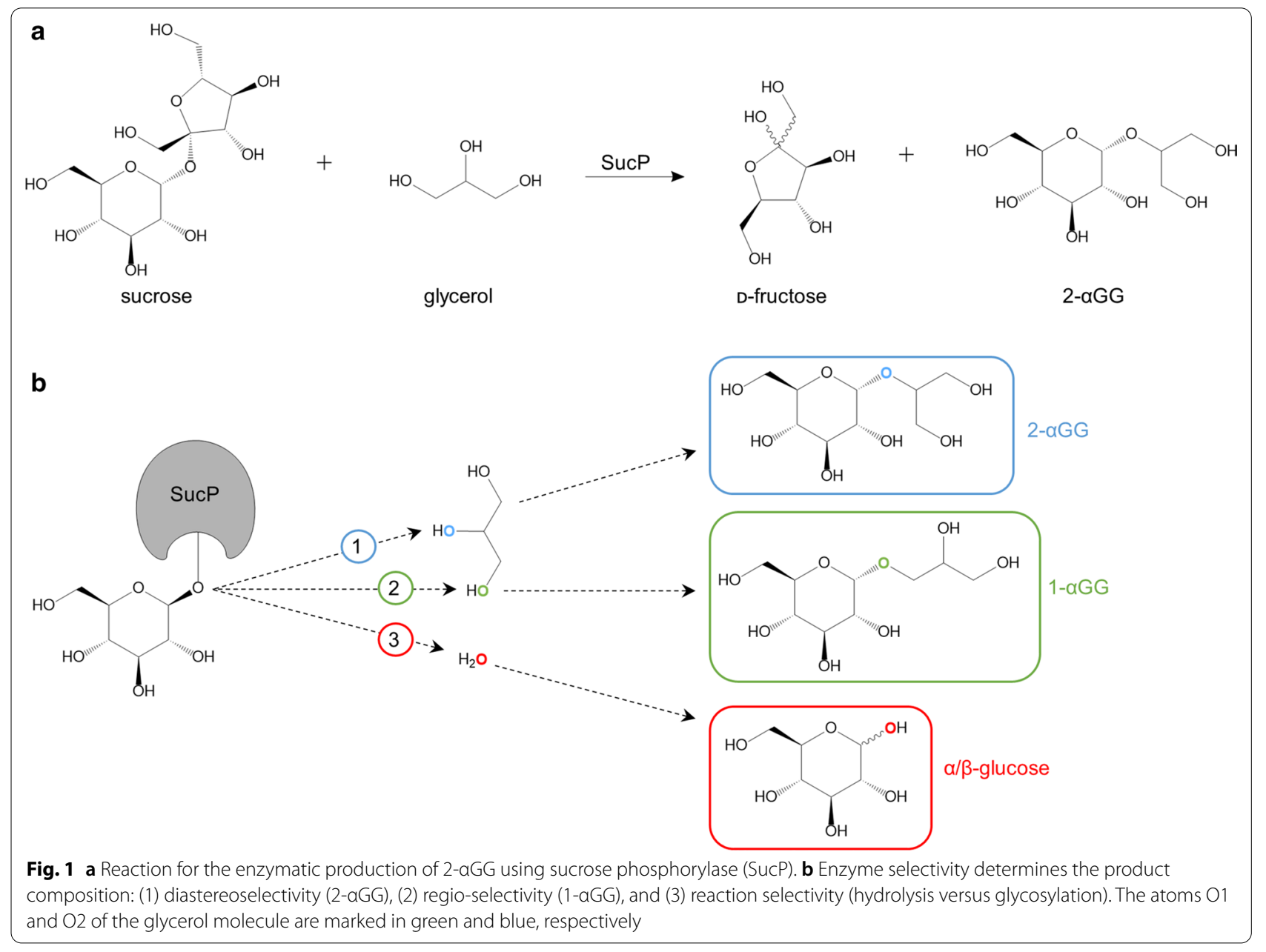

desert plant can survive complete desiccation over years, without losing tissue integrity [5]. The protection of cells and tissues (e.g., skin) is an important general function of compatible solutes [6,7], and this serves as the basis for promising applications in cosmetics $[8,9]$. GG specifically offers high capacity of water binding, to generate a strongly moisturizing effect when applied on the skin [10]. Besides cosmetic applications, GG has significant interest for use as low-calorie sweetener [11] that can have a prebiotic effect [12].

To support development for industrial applications, GG must be made available efficiently at large scale. Microbial production of GG may be limited in the output parameters achievable from the biosynthesis. Specifically, product concentration $(\leq 2 \mathrm{~g} / \mathrm{L})$, yield on substrates used $(\leq 0.1 \mathrm{~g} / \mathrm{g})$, and productivity $(\leq 0.04 \mathrm{~g} / \mathrm{L} / \mathrm{h})$ are rather low in engineered Corynebacterium glutamicum [13] and even lower in engineered cyanobacterial Synechocystis sp. strains [14]. Process engineering may require specialized approaches for which "bacterial milking" can be an example $[15,16]$. An efficient route of GG synthesis is glycosylation of glycerol from sucrose catalyzed by sucrose phosphorylase (SucP; Fig. 1a) [17]. Discovery of GG phosphorylases that catalyze 2-O- $\alpha$-glucosylation of glycerol from $\beta$-D-glucose 1-phosphate $[18,19]$ or $\alpha$-Dglucose 1-phosphate [20] has recently promoted alternatives of enzymatic GG synthesis, using two-enzyme phosphorylase cascade reactions. In these coupled reactions, either $\alpha$-D-glucose 1-phosphate $(\alpha$ Glc1-P) or $\beta$ Glc1-P is released in situ from sucrose or maltose to be used for glycosylation of glycerol [21]. Here, we are concerned with the simpler, single-enzyme reaction that yields GG directly from sucrose and glycerol (Fig. 1a).

The biocatalytic production relies on enzyme selectivity at three levels, as shown in Fig. 1b: diastereoselectivity for the $\alpha$ - or $\beta$-configuration in the product; regio-selectivity for position $\mathrm{O} 2$ or $\mathrm{O} 1$ in glycerol, and reaction selectivity (transfer to glycerol compared to hydrolysis). Used under suitable substrate conditions (e.g., 0.3-1.0 M sucrose; $\geq 1.5 \mathrm{M}$ glyceol) as reported previously [22], the SucP from Leuconostoc mesenteroides (LmSucP) enables efficient GG production with useful three-tier selectivity 
$[17,23,24]$. Sucrose is an excellent donor substrate for glycerol glycosylation in high yield $(\geq 90 \%)$ and with useful atom economy ( 50\%) [17]. GG is manufactured industrially by bitop AG (Dortmund, DE) using the biocatalytic process with LmSucP. GG is formulated into commercial product for cosmetic applications that is marketed as Glycoin ${ }^{\circledR}$ (a $50 \%$ solution of GG).

The GG process underlines the importance of SucP as an industrial enzyme. Glycosylation by SucP offers considerable scope in the products made [25]. Facile formulation of SucP into a ready-to-use, potentially recyclable catalyst is thus of interest. SucP has been immobilized variously on solid support [26-31] and CLEAs (crosslinked enzyme aggregates) of the SucP from Bifidobacterium adolescentis have been prepared [32]. Whole cell-based catalyst of Leuconostoc mesenteroides was used to produce $\alpha$-D-glucose 1-phosphate continuously from sucrose and phosphate [33]. Building on Escherichia coli as host for recombinant production of SucP, the analogous idea of whole cell biocatalysis was not explored. Considering the possibility of accumulating the SucP in large amounts in E. coli, the suitably formulated cells might constitute an attractive catalyst to be used in glycoside synthesis. Phosphorylase cascade reactions [21, $27,34,35]$ can likewise benefit from whole cell catalyst development.

Several studies show recombinant production of SucP enzymes in E. coli under standard conditions, apparently without major difficulties but also with quite variable efficiencies (see Table 1) [28, 36-43]. Systematic investigation of SucP expression has not been performed and inquiry focused on the development of an E. colibased whole cell catalyst of SucP is lacking. We here therefore studied the expression of $\mathrm{LmSucP}$ and $\mathrm{BaSucP}$ in a comparative, side by side fashion. The two enzymes are the best characterized among the SucPs (for review, see [25]) and they furthermore represent different structural prototypes within this enzyme group: the LmSucP is a functional monomer [38] whereas the BaSucP folds into a tightly associated homodimer [44]. We speculated that difference in the oligomeric structure might affect the producibility of soluble enzyme in E. coli. We show that insoluble protein formation was by far less pronounced with $\mathrm{LmSucP}(\leq 20 \%)$ than with BaSucP $(\sim 40 \%)$. We also show that, compared to BaSucP, LmSucP was preferred for regio-selective GG production. Expression from pET21 and pQE30 plasmids gave a high-yielding bioreactor production of the enzyme as a whole cell catalyst. Freeze-thaw treated cells were highly active and readily usable for practical synthesis of GG.

\section{Results and discussion}

Recombinant production of LmSucP and BaSucP with different expression systems

The LmSucP gene (GenBank identifier: D90314) is $1788 \mathrm{bp}$ in size and encodes a protein of $55.75 \mathrm{kDa}$. The BaSucP gene (GenBank identifier: AF543301) is $2400 \mathrm{bp}$ in size and encodes a protein of $56.20 \mathrm{kDa}$. Each protein is appended either at its authentic N-terminus (pQE30) or its authentic C-terminus (pET21) with a tag of 6

Table 1 Sucrose phosphorylase expression data from literature and from this study

\begin{tabular}{|c|c|c|c|c|c|}
\hline Enzyme & Native host & Expression strain & Specific activity of cell-free extract & $\%$ of total soluble protein & References \\
\hline \multirow[t]{4}{*}{ BaSP } & B. a. DSM 20083 & B. adolescentis & $0.84 \mathrm{U} / \mathrm{mg}$ & $0.80 \%$ & van den Broek et al. [36] \\
\hline & B. a. DSM 20083 & E. coli & 19.356 U/L cell culture & & van den Broek et al. [36] \\
\hline & B.a. LMG 10502 & E. coli Rosetta 2 & $1.5 \mathrm{U} / \mathrm{mL}$ cell culture (OD 1) & $(\sim 6 \%)$ & Aerts et al. [37] \\
\hline & B. a. DSM 20083 & E. coli BL21(DE3) & $38 \mathrm{U} / \mathrm{mg}$ & $33 \%$ & This study \\
\hline \multirow[t]{8}{*}{ LmSP } & L.m. DSM 20193 & L.m. DSM 20193 & $7 \mathrm{U} / \mathrm{mg}$ & $3.7 \%$ & Koga et al. [38] \\
\hline & & E. coli DH10B & $48 \mathrm{U} / \mathrm{mg}$ & $25 \%$ & Goedl et al. [28] \\
\hline & & E. coli BL21(DE3) & $55 \mathrm{U} / \mathrm{mg}$ & $30 \%$ & This study \\
\hline & L.m. ATCC 12291 & E. coli 1101 (slp-spl-1) & $55.7 \mathrm{U} / \mathrm{mg}$ & $30 \%$ & Kitoa et al. [39] \\
\hline & L.m. No. 165 & E. coli JM109 & $4.6 \mathrm{U} / \mathrm{mg}$ & $50 \%$ & Kawasaki et al. [40] \\
\hline & L.m & E. coli BL21(DE3) & $\begin{array}{l}\sim 22 \mathrm{U} / \mathrm{mg} \text { CDM } \\
(\sim 44 \mathrm{U} / \mathrm{mg} \text { CFE })\end{array}$ & $25 \%$ & Su et al. [41] \\
\hline & L.m. NRRL B-1149 & E. coli BL21(DE3)pLysS & $1.49 \mathrm{U} / \mathrm{mg}$ & Specific activities of enzymes & Lee et al. [43] \\
\hline & L. m. NRRL B-742 & E. coli BL21(DE3)pLysS & $1.8 \mathrm{U} / \mathrm{mg}$ & & Lee et al. [42] \\
\hline TtSP & $\begin{array}{l}\text { Thermoanaerobacte- } \\
\text { rium thermosaccharo- } \\
\text { lyticum }\end{array}$ & E. coli BL21(DE3) & $25.7 \mathrm{U} / \mathrm{mg}$ & $50 \%$ & Yao et al. [85] \\
\hline \multirow[t]{2}{*}{ BISP } & Bifidobacterium longum & E. coli BL21 & $13 \mathrm{U} / \mathrm{mg}$ & $11 \%$ & Hui Zhang [86] \\
\hline & & E. coli JM109 & $12.5 \mathrm{U} / \mathrm{mg}$ & $10 \%$ & Shin et al. [87] \\
\hline
\end{tabular}


histidines. The specific activities of the $\mathrm{N}$ - and $\mathrm{C}$-terminally tagged enzymes are $118 \pm 6 \mathrm{U} / \mathrm{mg}$ (mean of $N=6$ ) and $120 \pm 8 \mathrm{U} / \mathrm{mg}$ (mean of $N=8$ ) for BaSucP, respectively. They are $177 \pm 11 \mathrm{U} / \mathrm{mg}(N=7)$ and $174 \pm 10 \mathrm{U} /$ $\mathrm{mg}(N=5)$ for LmSucP, respectively. Literature values (120 U/mg for C-terminally tagged BaSucP [45]; $190 \mathrm{U} /$ $\mathrm{mg}$ for N-terminally tagged LmSucP [28]) were confirmed from this study.

The plasmid vectors pQE30 and pET21 were used for expression (Additional file 1: Figure S1). Both vectors are well characterized for recombinant protein production [46]. The main differences between the two are the following: The $\mathrm{T} 7_{\text {lacO }}$ promoter of $\mathrm{pET} 21$ is considered stronger than the $\mathrm{T} 5_{\text {laco }}$ promoter in pQE30 [47-49]. Genes encoding LacI (lac operon repressor) and Rop (repressor of primer) are present in pET21 but lacking in pQE30. These structural changes in plasmid imply a less tightly controlled expression from pQE30 than pET21 caused by the absence of LacI; and a 2 to 3-fold higher copy number of pQE30 compared to pET21 (15-50 copies per cell) [50-52] caused by the absence of Rop $[53,54]$, despite usage of the same origin of replication (pBR322). E. coli BL21(DE3) was used as the expression host. Induction was done identically with both vector systems, using isopropyl- $\beta$-D-thiogalactoside $(0.25 \mathrm{mM})$ and at $25{ }^{\circ} \mathrm{C}$. In shake flask cultivations, the maximum specific growth rate of E. coli BL21(DE3) during induction was measured (Additional file 1: Figure S2) and found to vary little with combination of insert and plasmid used $\left(\sim 0.72 \mathrm{~h}^{-1}\right)$, except for BaSucP_pET21 that caused slower growth $\left(0.55 \mathrm{~h}^{-1}\right)$.

Each insert-vector combination was characterized in two ways. Using SDS PAGE with densitometric analysis of protein bands (Additional file 1: Figure S3), the portion of recombinant enzyme in the insoluble protein fraction was quantitated relative to the soluble fraction from lysed cells (Fig. 2a). Secondly, the specific enzyme activity in the cell lysate was measured (Fig. 2a, b). LmSucP accumulated $\sim 40 \%$ of total protein and nearly all (pET21) or most ( $\geq 80 \%$; pQE30) of it was soluble (Fig. 2a, c). Production of BaSucP proceeded to higher levels using PQE30 ( 54\% of total protein) compared to pET21 ( 38\% of total protein) (Fig. 2a). Insoluble protein formation was more pronounced for BaSucP (pET21: 45\%; pQE30: 39\%) than it was for LmSucP (Fig. 2a, d). Specific activities obtained from three to five serial expression replicates were well consistent for BaSucP, giving $25 \pm 2 \mathrm{U} / \mathrm{mg}(N=3)$ and $38 \pm 1 \mathrm{U} / \mathrm{mg}(N=3)$ for the expression from pET21 and pQE30, respectively. For reasons unknowable from the current study, the specific activities of LmSucP showed larger variation $( \pm \sim 20 \%)$ across the serial replicates (Fig. 2a, b) than those of BaSucP. Using pET21 in particular (Fig. 2b), the specific activity of LmSucP started from a value of more than $100 \mathrm{U} / \mathrm{mg}$ in the first expression, which decreased to its almost half $(60 \mathrm{U} / \mathrm{mg})$ in the subsequent expression (Fig. 2b). On average, the specific activities were $62 \pm 5 \mathrm{U} / \mathrm{mg}(N=4$; which includes only rounds $2-5$ in Fig. $2 \mathrm{~b})$ and $54 \pm 9 \mathrm{U} / \mathrm{mg}(N=5)$ for the expression from pET21 and pQE30, respectively.

Table 1 summarizes the results of this study along with selected literature data on the production of LmSucP and $\mathrm{BaSucP}$ in the native organism or in E. coli. Differences in the conditions used make it impossible to compare the individual studies directly. Table 1 is nonetheless important to show the range of specific and volumetric activities obtained from the different approaches. Regarding enzyme production for high titer, the $\mathrm{pQE30-based}$ expression seems promising for both LmSucP and BaSucP. pQE30 is preferred over pET21 because expression was stronger with BaSucP and less variable in the specific activity obtained from LmSucP.

We considered reasons why in the case of BaSucP the expression from $\mathrm{pQE30}$ gave better results than the expression from pET21. Interestingly, it has been reported that the location of the His-tag $(\mathrm{N}-$ or $\mathrm{C}$-terminus) affects the expression levels of recombinant proteins [55-57]. A more recent study even observed a distinct over-expression of proteins with $\mathrm{N}$-terminal His-tags before induction (over $25 \%$ of total cellular protein) [58]. Hence, the N-terminal His-tag, together with the additional phase of low-level non-induced expression, that both only the expression from pQE30 involved, might be responsible for the higher BaSucP production. Moreover, in the phase of non-induced expression, as shown in Additional file 1: Figure S4B, most of the BaSucP was completely soluble. Therefore, the time for proper folding must have been sufficient for the recombinant enzyme formed and the concentration of aggregation-prone folding intermediate cannot have exceeded the solubility limit. The relatively smaller degree of insoluble protein received with LmSucP compared to BaSucP can arguably be ascribed to the more complex folding requirements of the latter enzyme, which is a functional homodimer. Sprogøe et al. [44] showed with the crystal structure of BaSucP that $\sim 4 \%\left(=\sim 960 \AA^{2}\right)$ of the total monomer surface area $\left(\sim 21,400 \AA^{2}\right)$ was buried within the dimer interface (see also Fig. 3). According to Nussinov [59], monomeric folding intermediates are stable when they are compactly folded and the monomer surface area buried upon dimerization is small. Protein compactness can be expressed from the ratio of monomer surface area and amino acid chain length. For BaSucP, compared to some other proteins [59], the compactness parameter $(41=21,400 / 519)$ together with the $4 \%$ buried surface area indicate that folding of the enzyme is likely to pass 

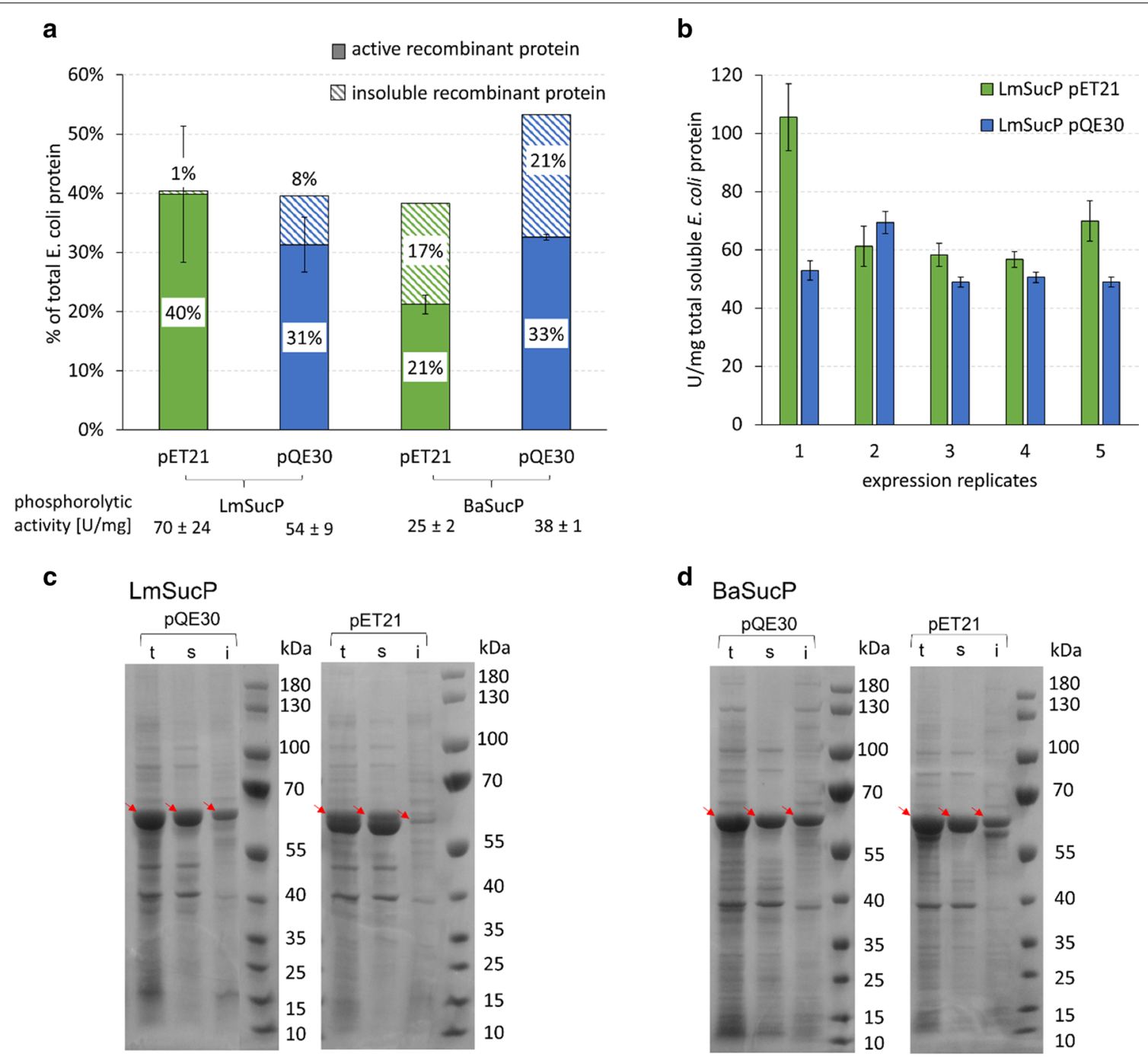

Fig. 2 Results of expression analysis. a Soluble and insoluble recombinant protein (LmSucP and BaSucP) percentage share of total soluble E. coli protein expressed by pQE30 and pET21 and corresponding phosphorolytic activity (U/mg total E. coli protein). One unit (U) of activity is the enzyme amount producing $1 \mu \mathrm{mol}$ aGlc1-P/min under the conditions used. Standard deviation $( \pm)$ was calculated from at least three expression replicates. b Expression replicates of LmSUCP from pET21 and PQE30, standard deviation was calculated from at least three analytical determinations. SDS PAGE gels of one representative expression replicate for $\mathbf{c} L \mathrm{LSUCP}(56.81 \mathrm{kDa}$ ) and $\mathbf{d}$ BaSucP $(57.50 \mathrm{kDa})$, respectively (see also Additional file 1: Figure S4)

through a rather stable, monomeric intermediate $[59,60]$. However, under conditions of induced expression, such intermediates can easily accumulate to levels that promote protein aggregation into an insoluble precipitate. Lastly, Additional file 1: Figure S4B shows evidence of protein degradation in the BaSucP produced by expression from pET21. A double band was visible at the BaSucP position in the gel when the whole E. coli protein or just the insoluble protein was analyzed. The protein band slightly smaller than the native BaSucP has likely arisen from partial proteolysis of the full-length protein at the intermediate stage of folding. Note that proteolytic degradation rarely happens in the insoluble protein [61].

\section{Regioselective glycosylation of glycerol for efficient synthesis of $G G$}

High-level expression for enzyme production in E. coli is useful in general to promote the various applications of LmSucP and BaSucP in glycoside synthesis $[21,25,34$, 62 ]. To select the most promising candidate for the whole 


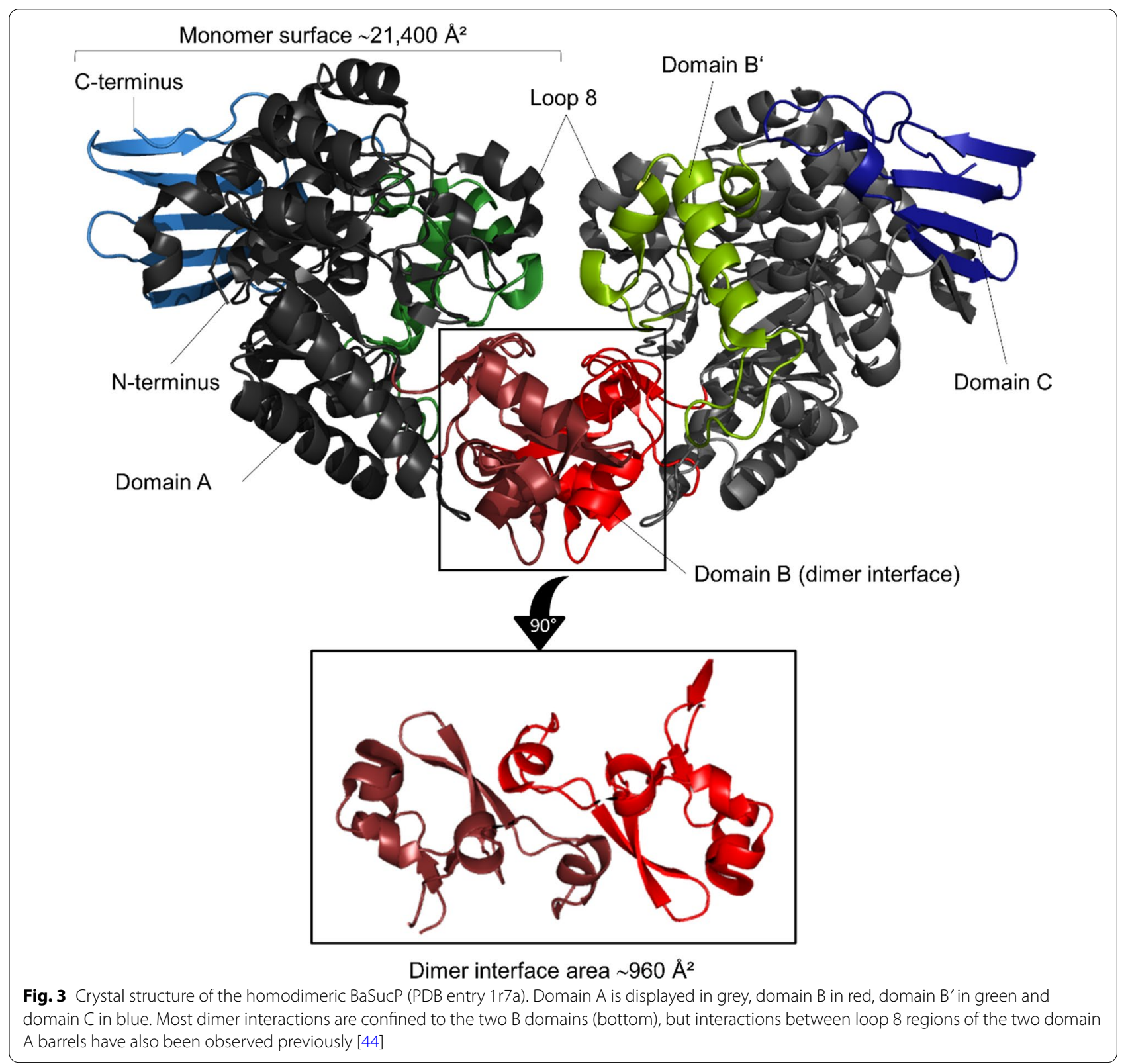

cell-catalyzed GG production, we first performed synthetic reactions using the cell lysates. Results of a comprehensive time course study are summarized in Fig. 4. A dedicated HPLC method was used to separate the relevant compounds for quantification in a single-run analysis (Fig. 4d). GG is distinguished from its regioisomer 1-O- $\alpha$-D-glucosyl glycerol (1-GG). Glycerol consumption was measured but is not shown, as it is related to the appearance of GG and 1-GG by mass balance. The results show the following (Fig. 4 and Additional file 1: Table S1): (1) Sucrose was used completely in both reactions. In the case that complete $(\geq 95 \%)$ conversion was demanded, the LmSucP reaction was faster ( 1.3-fold). (2) Both reactions released glucose due to hydrolysis of sucrose. Especially in the early reaction phase $(\sim 5 \mathrm{~h})$, LmSucP produced more glucose than BaSucP. This observation was consistent with a recent kinetic study that showed BaSucP to exhibit higher reaction selectivity (glycosylation of glycerol compared with hydrolysis) than LmSucP [63]. (3) Both enzymes formed 1-GG as secondary glycosylation product to GG. The portion of 1-GG in the product was $11 \%$ or smaller for LmSucP but reached $31 \%$ for 
a

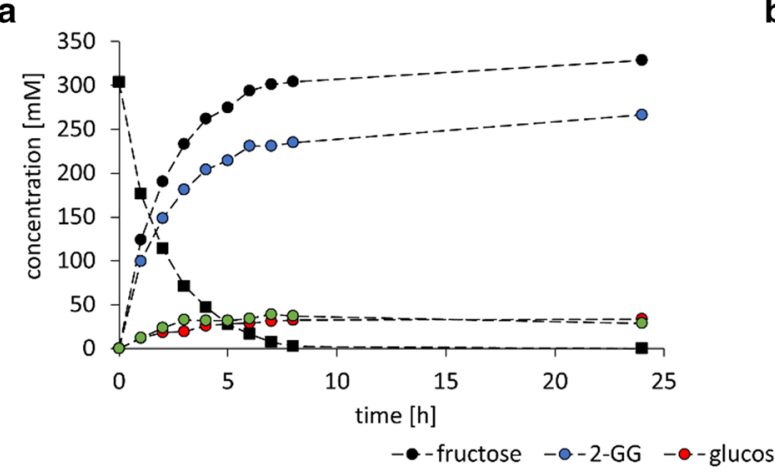

b

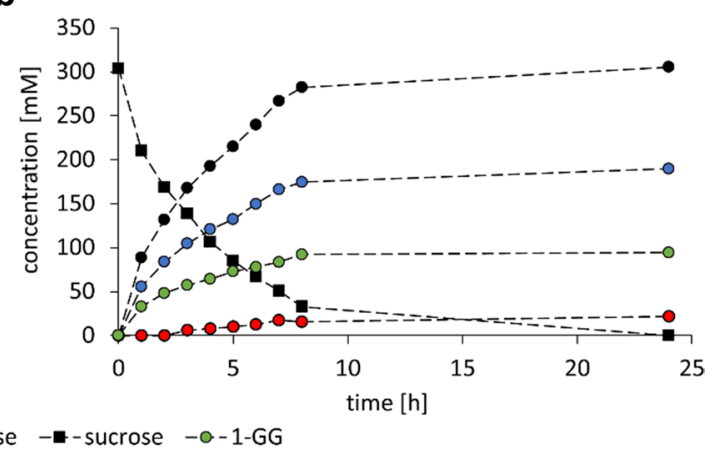

d c

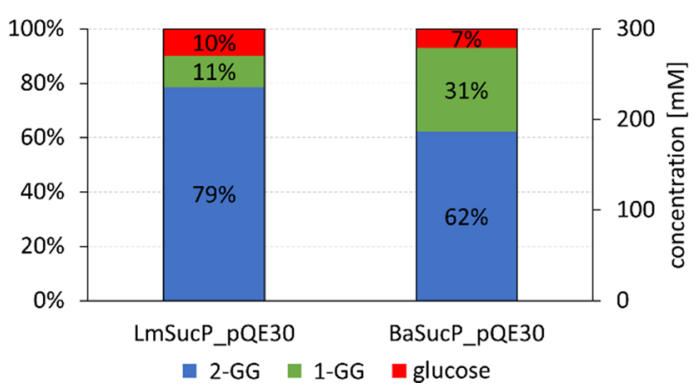

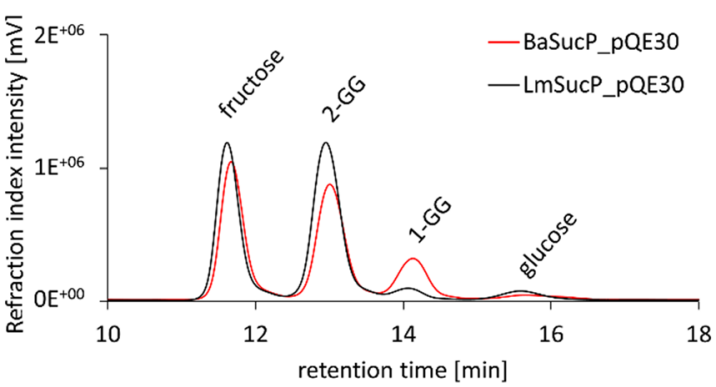

Fig. 4 Bioconversions of a LmSUcP_pQE30 and b BaSucP_pQE30 cell-free extracts. Reaction conditions: 300 mM sucrose, 1800 mM glycerol, $40 \mathrm{U} / \mathrm{mL}$ sucrose phosphorylase (phosphorolysis direction of the respective cell-free extract), $50 \mathrm{mM} \mathrm{MES}$ buffer at pH 7, $30^{\circ} \mathrm{C}, 300 \mathrm{rpm}$ for $24 \mathrm{~h}$. $\mathbf{C}$ Product composition after $24 \mathrm{~h} \mathrm{GG}$ production and $\mathbf{d}$ corresponding chromatograms of HPLC measurements

BaSucP (Fig. 4c). The regioselectivity of neither enzyme was perfect but that of BaSucP was not sufficient for GG production.

Glycerol docking into the structure of the covalent $\beta$-glucosyl enzyme intermediate of LmSucP (modelled from the experimental $\mathrm{BaSucP}$ structure) has previously suggested a plausible mode of glycerol binding for glycosylation at its $\mathrm{O} 2$ [64]. The alternative mode of glycerol binding for glycosylation at its $\mathrm{O} 1$ is unknown. The BaSucP structure reveals two mobile loops that line the binding pocket for the acceptor substrate (Fig. 5). These loops undergo structural rearrangement during the catalytic cycle to enable binding of both fructose and phosphate in the canonical reaction of the enzyme (phosphorolysis of sucrose) $[45,65,66]$. It stands to reason based on chemical intuition that the glycerol acceptor would be accommodated rather in the acceptor binding pocket shaped for fructose binding than in the pocket shaped for phosphate binding. However, the high structural flexibility of the acceptor binding pocket might allow for glycerol binding in different orientations and could thus be responsible for the low regioselectivity of BaSucP in the reaction with glycerol. The amino acids making the acceptor binding pocket of the BaSucP structure are well conserved in LmSucP [24]. Structural interpretation of enzyme regioselectivity different in LmSucP and BaSucP must await evidence on glycerol binding at atomic resolution in at least one, but ideally both enzymes.

\section{Controlled bioreactor cultivation for LmSucP production}

To increase the cell concentration in the E. coli cultivation, we performed carbon-limited fed-batch bioreactor experiments $(1.5 \mathrm{~L}$; working volume $1.2 \mathrm{~L})$ using minimal medium. By using an exponential substrate feed, the specific growth rate $\mu$ was adjusted to $0.05 \mathrm{~h}^{-1}$. This $\mu$ was 6 times smaller than the average $\mu\left(0.3 \mathrm{~h}^{-1}\right)$ in the shake flask cultivation. Strains harboring LmSucP_pQE30 and LmSucP_pET21 were assessed in parallel experiments at $25{ }^{\circ} \mathrm{C}$ and $28^{\circ} \mathrm{C}$. The conditions were chosen because of results from shaken flask experiments suggesting a critical influence of cultivation temperature in just that range, as discussed below. An exemplary description of the measurement and control parameters in the course of time of all four bioreactor cultivations is given in Fig. 6a. The cells could maintain the predefined growth rate over almost the whole production phase, only a marginal deviation was observed at the end of the cultivation, as shown in Fig. 6b. In all cultivations, irrespective of the plasmid 


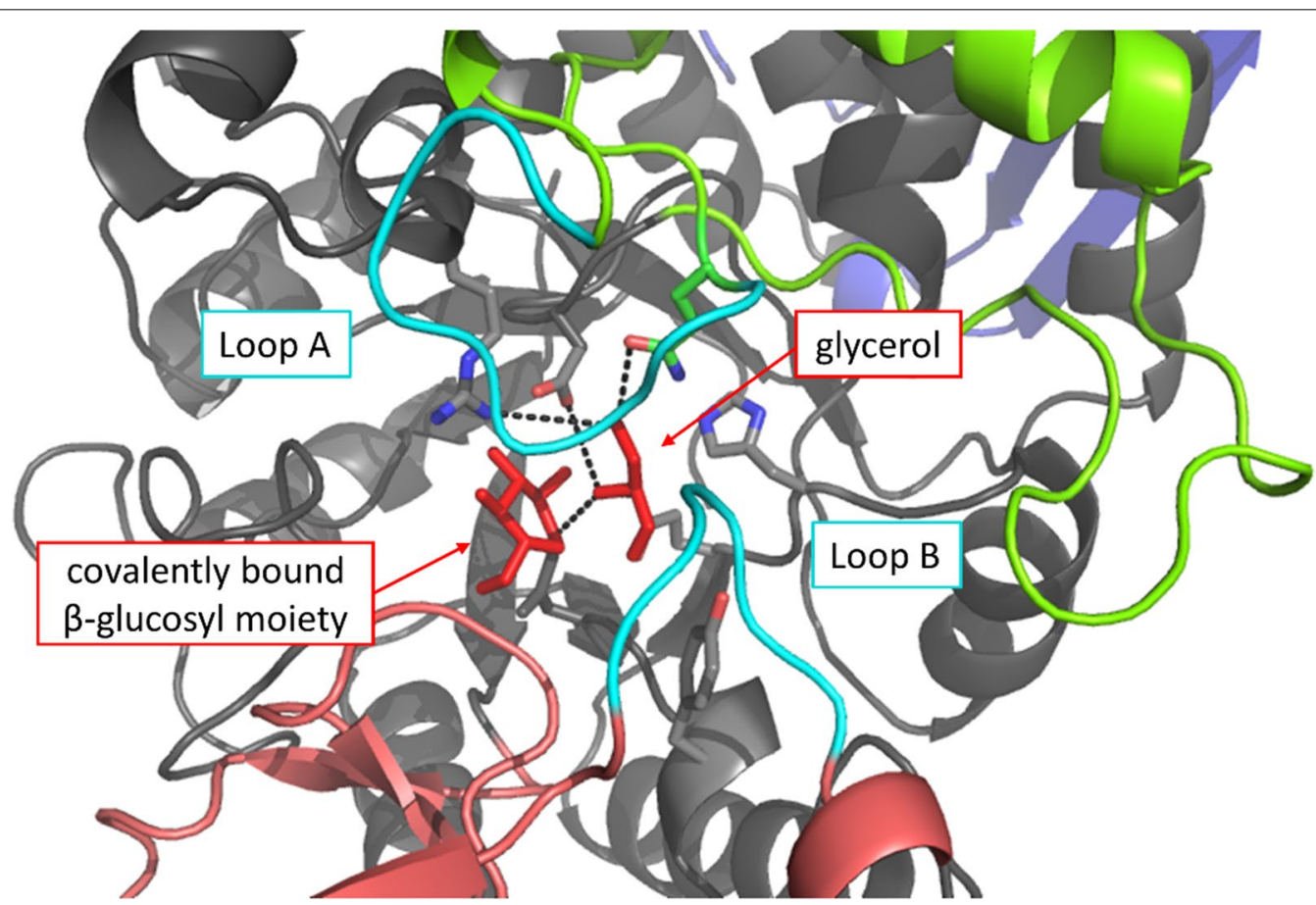

Fig. 5 Positioning of glycerol in BaSucP for regioselective glycosylation at O2. Illustration of mobile loops (cyan) and binding pocket for acceptor substrate of the $\beta$-glucosyl enzyme intermediate of BaSucP (PDB-entry $2 \mathrm{gdv}$, molecule A). Interactions of a previously performed glycerol acceptor docking experiment [67] are shown. Color code for enzyme domains corresponds to Fig. 3

vector and the temperature used, an $E$. coli cell density of $\sim 40 \mathrm{~g} / \mathrm{L}$, equivalent to $\sim 50 \mathrm{~g} \mathrm{CDM}$, was reached. The used cultivation and induction strategy led to soluble LmSucP production and gave high volumetric yields (up to $4 \mathrm{~g} / \mathrm{L}$ ) at the end of the process. Excessive formation of insoluble protein was not observed.

Enzyme production in shaken flasks at $28{ }^{\circ} \mathrm{C}$ gave a considerably lower specific activity of LmSucP (pET21: 2.2-fold; pQE30: 4.4-fold) compared to enzyme production at $25^{\circ} \mathrm{C}$ (Fig. 7a). The effect can be ascribed to a substantially larger portion of LmSucP found as insoluble protein at $28{ }^{\circ} \mathrm{C}$ than at $25{ }^{\circ} \mathrm{C}$ (Fig. $7 \mathrm{~b}$ ). Remarkably, an increase in temperature by just $3{ }^{\circ} \mathrm{C}$ caused the soluble/ insoluble protein ratio for $\mathrm{LmSucP}$ to become inverted at $28{ }^{\circ} \mathrm{C}$ (Fig. 7b, Additional file 1: Figure S5). The lack of measurement and control in the shake flask cultivation makes it difficult to identify the possible origin of what we consider an unusual temperature sensitivity of the recombinant protein production in E. coli. Interestingly, in terms of LmSucP specific activity achieved, enzyme production in the bioreactor was largely independent of the temperature in the range studied (Fig. 7). Presumably, in consequence of the restricted growth rate due to feed control, the formation of insoluble recombinant protein was completely suppressed at both $25{ }^{\circ} \mathrm{C}$ and $28{ }^{\circ} \mathrm{C}$ in the bioreactor (Additional file 1: Figure S6). The specific activities from the bioreactor cultivations were lower than from shake flask cultivations at $25{ }^{\circ} \mathrm{C}$ (pET21: 2.2fold; pQE30: 3.8-fold) but comparable at $28{ }^{\circ} \mathrm{C}$ (Fig. 7a). Overall, normalized on the working volume $(1.2 \mathrm{~L})$, the fed-batch bioreactor production yielded $7.6 \times 10^{5} \mathrm{U} / \mathrm{L}$ and $2.5 \times 10^{5} \mathrm{U} / \mathrm{L}$ LmSucP using expression from $\mathrm{pET} 21$ and $\mathrm{pQE30}$, respectively. The corresponding productivity was $3.2 \times 10^{4} \mathrm{U} / \mathrm{h}$ and $1.0 \times 10^{4} \mathrm{U} / \mathrm{h}(28 \mathrm{~h}$ after induction) and the whole cell activity normalized on the cell dry mass was $2.0 \times 10^{4} \mathrm{U} / g$ and $6.5 \times 10^{3} \mathrm{U} / \mathrm{g}$. Even at this stage of development without dedicated optimization, the enzyme production in the fed-batch bioreactor can be considered efficient. The specific enzyme activity in cell lysate was retained largely while taking the LmSucP production from the shake flask to the bioreactor. However, high sensitivity of the soluble/insoluble protein ratio in the shake flask production to tiny change in temperature $\left(25^{\circ} \mathrm{C} \rightarrow 28{ }^{\circ} \mathrm{C}\right)$ was an unexpected phenomenon. Since the same temperature effect was completely absent in the bioreactor cultivation, it could not have originated from the enzyme intrinsically. The fundamental problem of unknown system parameter(s) affecting the output of recombinant protein production in the shake flasks is therefore emphasized. These results strongly support 

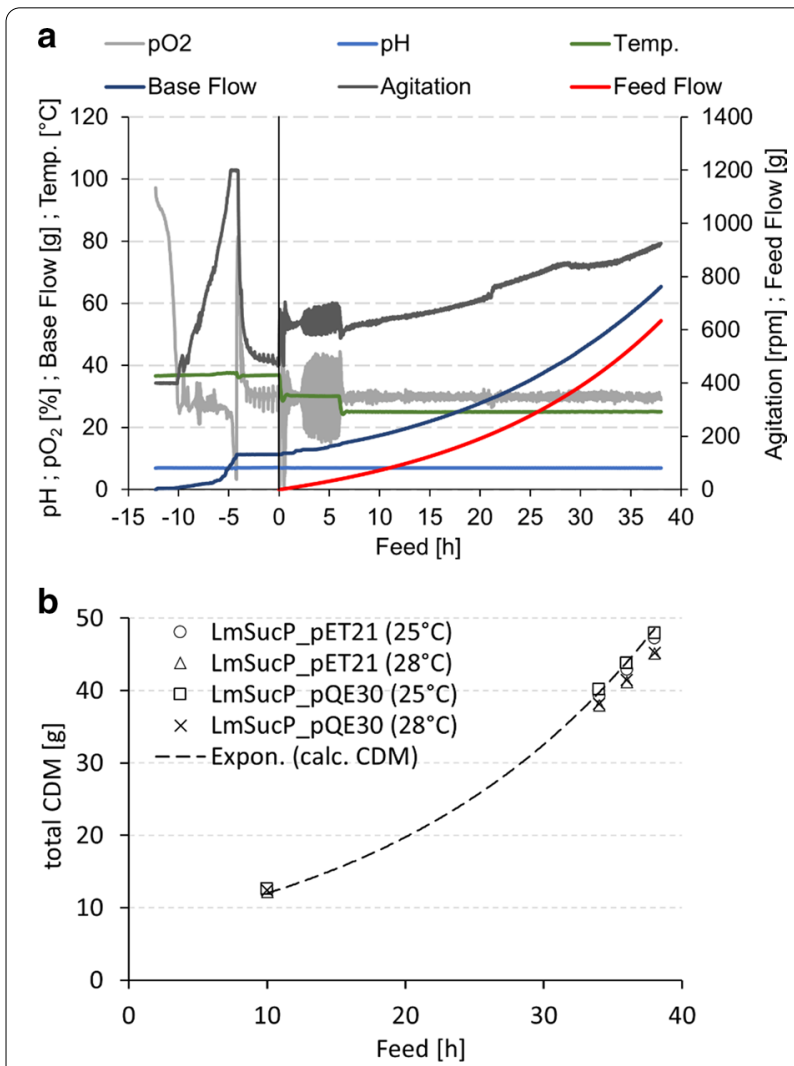

Fig. 6 Fed-batch bioreactor cultivation. a Example time course with control parameters shown (LmSucP_pET21 at $\left.25^{\circ} \mathrm{C}\right)$. b Cell dry mass formation and calculated cell dry mass for the different cultivations

early integration of bioreactor studies into the development of recombinant enzyme production in E. coli.

\section{Whole cell-based catalyst for $\mathrm{GG}$ production}

Assuming an overall protein concentration in the E. coli cytoplasm of $\sim 300 \mathrm{~g} / \mathrm{L}$ [68], we can use the result from Fig. 2a ( $\sim 40 \% \mathrm{LmSP}$ of total intracellular protein) to estimate an enzyme concentration of $\sim 120 \mathrm{~g} / \mathrm{L}$ in induced E. coli BL21(DE3) cells harboring LmSucP_pET21 or LmSucP_pQE30. Considerable processing effort would be necessary to establish a similarly concentrated state for the (partially) isolated enzyme. However, whole cell-based enzyme formulations can retain the LmSucP highly concentrated as produced by recombinant protein biosynthesis. Moreover, the number of processing steps for catalyst preparation can be reduced when whole cells are used. Permeabilization of the cells is usually necessary to make available the intracellularly localized enzyme activity for the synthetic reaction, unmasked from effects of transport across the cell membrane. A large set of methods exists for cell permeabilization [6974]. A balance between unmasking the enzyme activity and enzyme leakage from the cells must be achieved. We here focused on "physical permeabilization" by freezing and thawing or freeze-drying. Both processes are mild in destabilizing the whole cell integrity $[75,76]$. They are benign in that organic solvents are not used. Chemicals (e.g., detergents) that are difficult to remove later are not introduced.

To assess the different whole cell preparations of LmSucP for GG production, we performed synthetic reactions and evaluated the performance against cell lysate as the reference. Reaction time courses are shown in Fig. 8 and key parameters of conversion efficiency calculated from the data are summarized in Table 2 . The non-permeabilized cells expressed only $\sim 14 \%$ of the reference activity $(850 \mathrm{U} / \mathrm{g} \mathrm{CDW})$. Freeze-thawing and freeze-drying were similar in achieving $\sim 71 \%$ and $\sim 65 \%$ of the reference activity. However, enzyme leakage to supernatant was lower for freeze-thawed cells $(\sim 1 \%)$ compared to freeze-dried cells ( $5 \%)$. The freeze-thawed cells may thus be suitable for encapsulation to facilitate recycling. The space-time yield after $\sim 95 \%$ sucrose conversion was slightly higher (1.6-fold) with the cell lysate compared to freeze-thawed whole cells (Table 2). The final GG yield was however similar with both catalyst preparations. In summary, freeze-thaw treatment appears to be suitable for $E$. coli cell permeabilization. It yields a LmSucP whole cell catalyst that is highly active and avoids enzyme leakage from the solid material.

\section{Conclusions}

This systematic study of plasmid-based expression in E. coli of LmSucP and BaSucP shows accumulation of recombinant protein to levels of $\sim 50 \%$ of total intracellular protein. The simpler monomeric structure of LmSucP compared to the homodimeric structure of BaSucP favors soluble expression. Specific phosphorolytic activities of up to $35,000 \mathrm{U} / \mathrm{g} C D M$ (corresponding to $70 \mathrm{U} / \mathrm{mg}$ total protein) were obtained, supporting the development of a whole cell-based catalyst of both enzymes. For GG production, $\mathrm{LmSucP}$ is the preferred choice due to its higher regioselectivity compared to BaSucP. The enzyme production for LmSucP was scalable to fed-batch bioreactor cultivation ( $1.2 \mathrm{~L}$ volume) that resulted in $\sim 40 \mathrm{~g} \mathrm{CDW} / \mathrm{L}$ and $7.6 \times 10^{5} \mathrm{U} / \mathrm{L}$. The freeze-thaw treated cells are a highly active, solid formulation of LmSucP for practical synthesis of GG. An industrial relevant space time yield of $10 \mathrm{~g} / \mathrm{L} / \mathrm{h}$, according to Woodley et al. [77], was almost achieved $(\sim 8 \mathrm{~g} / \mathrm{L} / \mathrm{h})$ even without optimizing synthesis conditions. This underlines the catalyst's applicability for industry. Finally, the current study supports the notion that expression optimization should integrate controlled bioreactor experiments at an early stage of development. 


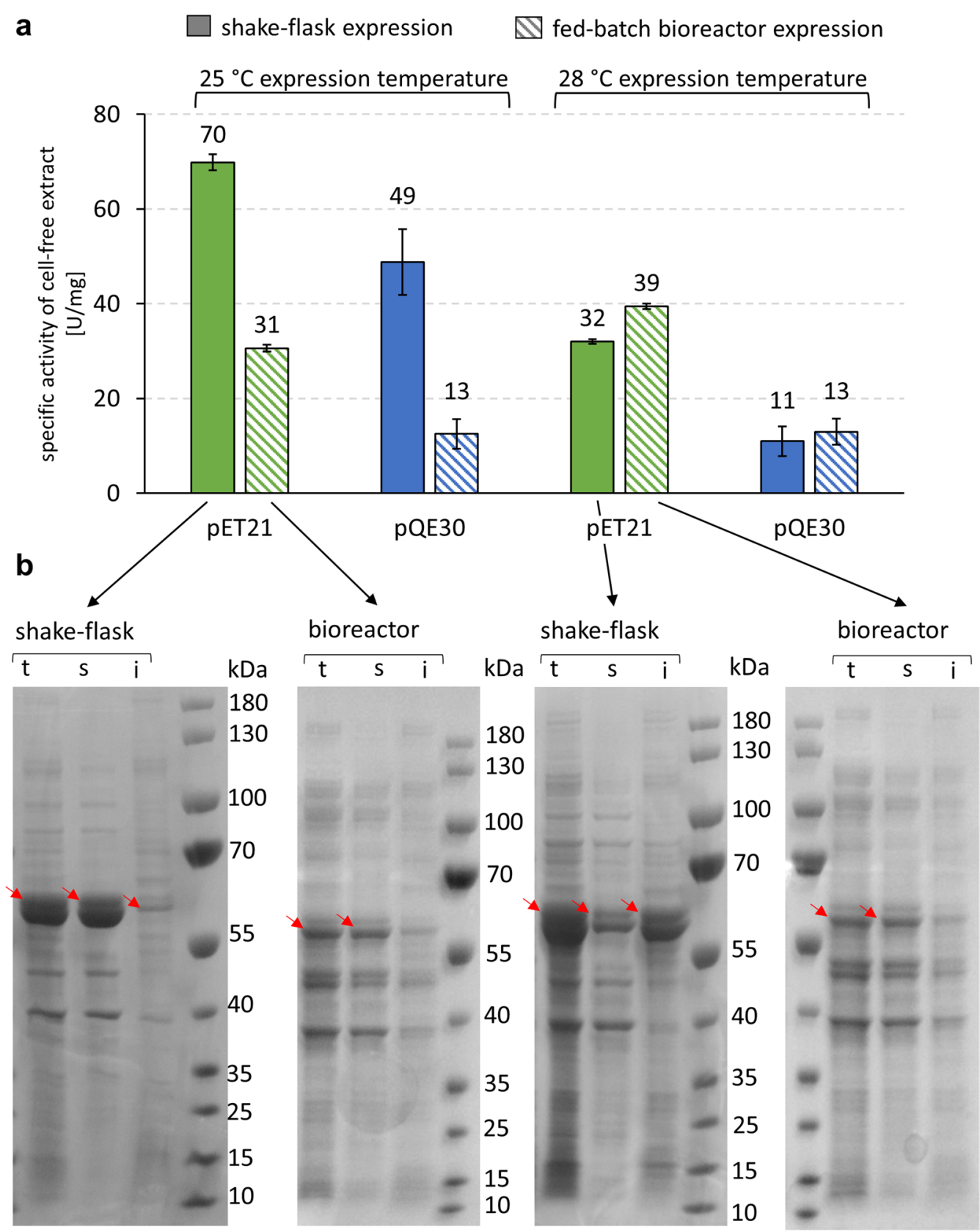

t...total protein s...soluble protein i...insoluble protein

Fig. 7 Fed-batch bioreactor expression versus shake-flask expression of LmSuCP_pQE30 and LmSucP_pET21 at two expression temperatures $\left(25^{\circ} \mathrm{C}\right.$ and $28^{\circ} \mathrm{C}$ ). a Specific phosphorolytic activities of cell-free extracts. Standard deviations were calculated from at least three analytical determinations. b Corresponding SDS PAGE gels of LmSucP_pET21

The fed-batch cultivations reported here might be even further miniaturized to $\sim 1 \mathrm{~mL}$ to enhance parallelization capacity [78].

\section{Materials and methods}

\section{Strain generation}

The genes for LmSucP (GenBank identifier: D90314) and BaSucP (GenBank identifier: AF543301) were 


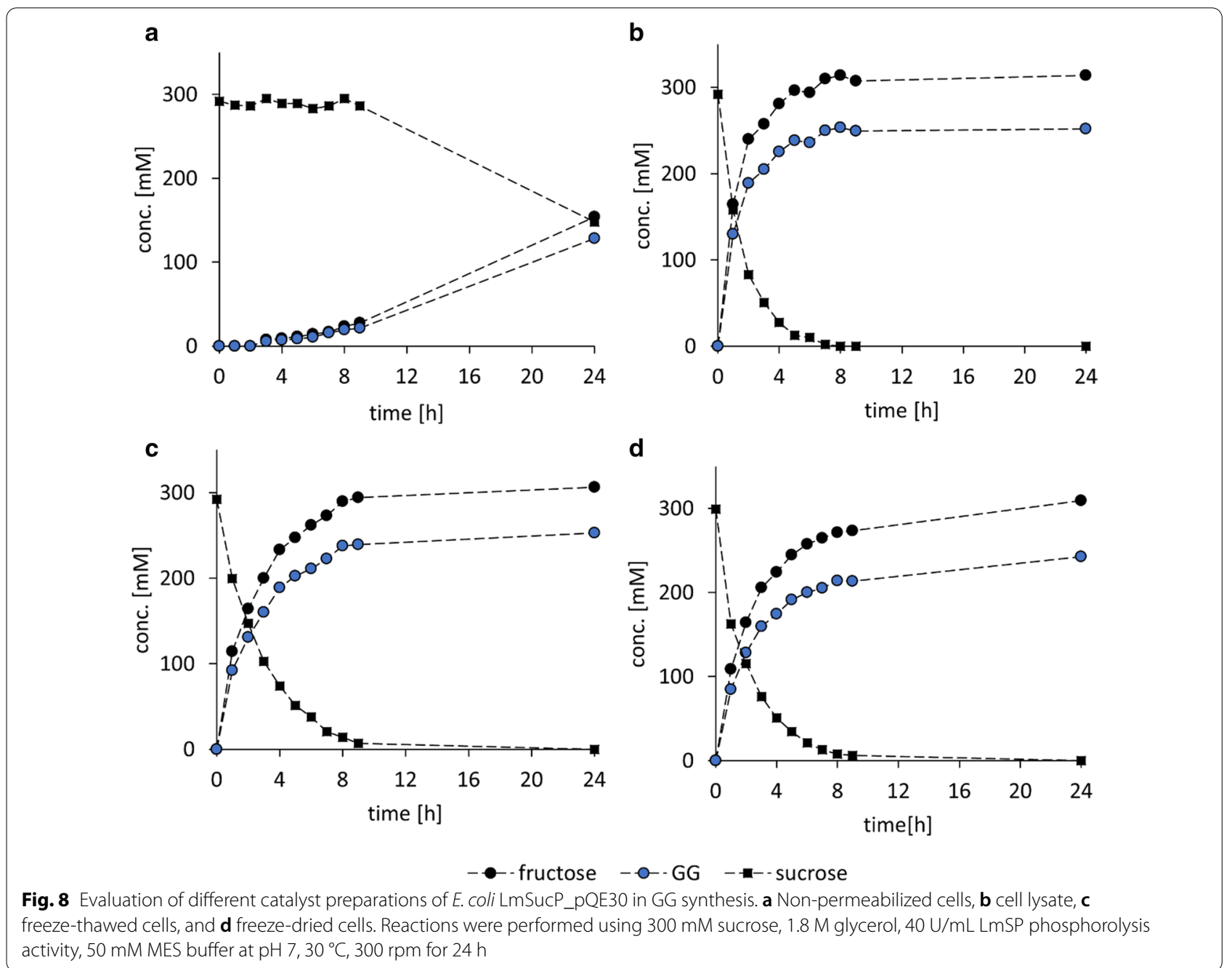

Table 2 Efficiency parameters of different cell catalysts (LmSP_pQE30) preparations in GG synthesis

\begin{tabular}{|c|c|c|c|c|c|c|}
\hline \multirow[t]{2}{*}{ Treatment } & \multicolumn{2}{|c|}{ GG yield } & \multirow{2}{*}{ 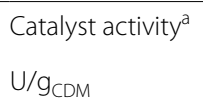 } & \multirow{2}{*}{$\begin{array}{l}\text { GG concentration } \\
g / L\end{array}$} & \multirow{2}{*}{$\begin{array}{l}\text { Space-time yield } \\
\text { g/L/h }\end{array}$} & \multirow{2}{*}{$\begin{array}{l}\text { Reaction } / \text { site }^{d} \text { selectivity } \\
\%\end{array}$} \\
\hline & 2 h (\%) & 24 h (\%) & & & & \\
\hline Non-permeabilized & 0 & 44 & 11.5 & 32.6 & 1.4 & $93 / 88$ \\
\hline Extracted & 65 & 86 & 846 & 64.0 & 12.1 & $89 / 88$ \\
\hline Freeze-thawed & 45 & 86 & 598 & 64.3 & 7.6 & $92 / 88$ \\
\hline Freeze-dried & 42 & 80 & 553 & 61.7 & 7.5 & $87 / 88$ \\
\hline
\end{tabular}

a One $U$ is the enzyme amount producing $1 \mu \mathrm{mol} \mathrm{GG/min}$

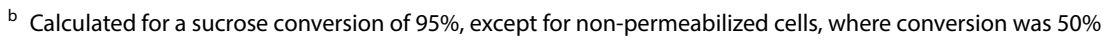

$c, d$ Percent ratio of ${ }^{c} \mathrm{GG}$ formed/Fru released (= sucrose converted) and ${ }^{\mathrm{d}} \mathrm{GG} /(1-\mathrm{GG}+\mathrm{GG}$ )

used in pET21 or pQE30 plasmid vectors. Both genes were codon-optimized for expression in E. coli (GenScript Biotech Corp., Piscataway, NJ, USA). E. coli Top10F' was used for plasmid amplification, E. coli BL21(DE3) for expression. Cells were transformed by electroporation [79], regenerated in $1 \mathrm{~mL}$ SOC medium [80] for $1 \mathrm{~h}$ at $37^{\circ} \mathrm{C}$, and selected on lysogeny broth (LB)-agar plates containing $100 \mathrm{mg} / \mathrm{L}$ ampicillin. 


\section{Cell preparation}

E. coli strains were grown at $37^{\circ} \mathrm{C}$ in LB-medium $(5 \mathrm{~g} / \mathrm{L}$ $\mathrm{NaCl}, 5 \mathrm{~g} / \mathrm{L}$ yeast extract, $10 \mathrm{~g} / \mathrm{L}$ peptone from casein) in baffled shake flasks containing $100 \mathrm{mg} / \mathrm{L}$ ampicillin. The main culture $(250 \mathrm{~mL}$ in $1 \mathrm{~L}$ flasks) was inoculated with cells from an overnight grown preculture (50 mL in $300 \mathrm{~mL}$ flasks). Biomass was grown to $\mathrm{OD}_{600}$ of $0.8-1.0$ and expression was induced with $0.25 \mathrm{mM}$ isopropyl- $\beta$-D-thiogalactopyranoside (IPTG). Incubation was overnight at $25{ }^{\circ} \mathrm{C}$ and $110 \mathrm{rpm}$ in incubation shaker CERTOMAT BS-1 (Sartorius, Göttingen, DE). $\mathrm{OD}_{600}$ was measured spectrophotometrically $\left(\mathrm{DU}^{\circledR} 800\right.$ UV/Vis Spectrophotometer, Beckman Coulter, Brea, CA, USA). Cell dry mass (CDM) was determined by filtering cell culture $(15-20 \mathrm{~mL})$ over pre-weighed Whatman ${ }^{\circledR}$ Nuclepore $^{\mathrm{TM}}$ TrackEtched membrane (diameter $50 \mathrm{~mm}$, pore size $0.4 \mu \mathrm{m}$, polycarbonate, Sigma Aldrich/Merck, Darmstadt, DE). Washed cells (10-15 mL water) were dried overnight at $70{ }^{\circ} \mathrm{C}$ and weighed. Centrifuged cells (20 min, $4{ }^{\circ} \mathrm{C}$, $4.4 \mathrm{krcf}$, Ultracentrifuge Sorvall RC-5B Superspeed) were resuspended in $50 \mathrm{mM}$ MES buffer, pH 7.0 (6:1 cell wet weight, v:w), aliquoted $(\sim 15 \mathrm{~mL}$ portions) and stored at $-80{ }^{\circ} \mathrm{C}$ until further use. Nonpermeabilized and freeze-dried cells were processed immediately without an intermediate freezing step.

To prepare the cell lysate, an aliquot of the cell suspension was thawed and ultra-sonicated (Branson Ultrasonics $^{\text {TM }}$ Microtips Probe $1 / 8^{\prime \prime}$ dia 418-A, Thermo Fisher Scientific Inc., Waltham, MA, USA) using three times a 6 -min run ( 2 s pulse on, 4 s pulse off, $30 \%$ amplitude). Centrifuged cell extract $\left(21.1 \mathrm{krcf}, 4{ }^{\circ} \mathrm{C}\right.$ for $45 \mathrm{~min}$, Centrifuge Eppendorf 5424R, Eppendorf, Hamburg, DE) was immediately used for enzyme activity determination and subsequently stored at $-20^{\circ} \mathrm{C}$.

\section{Expression analysis}

Enzyme activities were determined in phosphorolysis direction by a continuous coupled activity assay [81]. The $\alpha$ Glc1-P liberated on enzyme action was converted by phosphoglucomutase from rabbit muscle (3 U/mL, Sigma-Aldrich/Merck, Darmstadt, DE) and $\mathrm{NAD}^{+}$-dependent $\mathrm{D}$-glucose-6-phosphate dehydrogenase from Leuconostoc mesenteroides (3.4 U/mL, SigmaAldrich/Merck, Darmstadt, DE) to NADH, which then was monitored spectrophotometrically at $340 \mathrm{~nm}\left(\mathrm{DU}^{\circledR}\right.$ 800 UV/Vis Spectrophotometer, Beckman Coulter, Brea, CA, USA, see Additional file 1 for details). The protein concentration was determined according to the manual of Carl Roth GmbH (Karlsruhe, DE). The sample $(10 \mu \mathrm{L})$ was mixed with $500 \mu \mathrm{L}$ of the fivefold diluted Roti ${ }^{\circledR}$-Qant $5 \times$ concentrate (Carl Roth $\mathrm{GmbH}$ ). After 15 min incubation at room temperature, the absorbance was measured at $595 \mathrm{~nm}\left(\mathrm{DU}^{\circledR} 800 \mathrm{UV} /\right.$ Vis Spectrophotometer).
The protein concentration was calculated from a calibration curve in the range of 0.1 to $1.0 \mathrm{~g} / \mathrm{L}$ protein (bovine serum albumin, Sigma-Aldrich/Merck, Darmstadt, DE). To obtain comparable activity measurements, the total protein concentration was considered the basis for calculating the activity (Units/mg total soluble E. coli protein). The portion of enzyme in total soluble $E$. coli protein was calculated from the specific activities of cell-free extract and isolated enzyme.

Overexpression of the enzymes was additionally checked by SDS PAGE. Ten microlitre of the sample was loaded on a NuPAGE $4-12 \%$ Bis-Tris Protein Gel (Thermo Fisher Scientific Inc., Waltham, MA, USA). The protein separation was performed at $175 \mathrm{~V}$ for $75 \mathrm{~min}$ in $1 \times$ MOPS buffer (NuPAGE MOPS SDS Running Buffer $20 \times$, Invitrogen). The finished gel was stained with staining solution (75:500:425; acetic acid:ethanol:water; v:v:v; $2.5 \mathrm{~g} / \mathrm{L}$ of Brilliant blue R250) for $\sim 30 \mathrm{~min}$ and destained (75:200:725; acetic acid:ethanol:water, v:v:v) to visualize the protein bands.The portion of insoluble protein relative to soluble protein was determined by band intensity measurements using ImageJ. Lane profile plots were generated by the "gel analysis method" outlined in the ImageJ documentation [82]. See Additional file 1: Figure S3 for one representative SDS PAGE image and corresponding lane profile plots.

\section{Fed-batch bioreactor cultivations}

Cells were grown in a $1.5 \mathrm{~L}(1.2 \mathrm{~L}$ working volume, $0.4 \mathrm{~L}$ minimal volume) DASGIP ${ }^{\circledR}$ Parallel Bioreactor System (Eppendorf AG, Hamburg, DE) equipped with a $\mathrm{pH}$ probe (Hamilton Bonaduz AG, Bonaduz, $\mathrm{CH}$ ), an optical DO probe (Hamilton Bonaduz AG), and a DASGIP ${ }^{\circledR}$ GA4X-module (Eppendorf AG) for online off-gas monitoring. The $\mathrm{pH}$ was maintained at $7.0 \pm 0.05$ with $12.5 \%$ ammonia solution (Thermo Fisher Scientific, Waltham, USA). The temperature was $37 \pm 0.5^{\circ} \mathrm{C}$ during the batch phase and decreased to $30 \pm 0.5^{\circ} \mathrm{C}$ at the beginning of the feed phase. The recombinant production was initiated after $6 \mathrm{~h}$ from feed start and the temperature was set to $28 \pm 0.5^{\circ} \mathrm{C}$ and $25 \pm 0.5^{\circ} \mathrm{C}$, respectively. The dissolved oxygen $\left(\mathrm{O}_{2}\right)$ level was stabilized at $\geq 30 \%$ saturation by controlling the stirrer speed and the aeration rate. Foaming was suppressed with the antifoam suspension Glanapon 2000 (Bussetti \& Co GmbH, Vienna, AT).

The composition of the batch and the fed-batch medium used for cultivation is described elsewhere [83]. All media components were added in relation to the calculated grams cell dry mass (CDM) to be produced and the specific yield coefficient $\left(Y_{x / s}=0.3\right.$ gbiomass $\left./ g_{\text {substrate }}\right)$ for BL21(DE3). Ampicillin (100 mg/L) was added to avoid plasmid loss. Pre-cultures were grown in semi synthetic media and thereof $25 \mathrm{OD}_{600}$ units $\left(25 / \mathrm{OD}_{600}=\right.$ volume 
in $\mathrm{mL}$ ) were transferred aseptically to the bioreactors. Feeding was initiated when the culture entered the stationary phase ( $10 \mathrm{~g} / \mathrm{L} \mathrm{CDM} \mathrm{in} 0.6 \mathrm{~L}$ batch medium). A fed-batch regimen with exponential carbon-limited substrate feed was used to provide a constant growth rate of $\mu=0.05 \mathrm{~h}^{-1}$ throughout $38 \mathrm{~h}$ or 2.74 doublings. The substrate feed was controlled by increasing the pump speed according to the exponential growth algorithm, $\mathrm{x}=\mathrm{x}_{0} \mathrm{e}^{\mu \mathrm{t}}$, with superimposed feedback control of weight loss in the substrate bottle. Expression of LmSucP was induced $10 \mathrm{~h}$ after feed start, by adding $2 \mu \mathrm{mol}$ IPTG per g calculated CDM to achieve protein production for two generations.

For off-line analysis $\left(\mathrm{OD}_{600}, \mathrm{CDM}\right.$, product), samples were taken before induction, and 24, 26, and $28 \mathrm{~h}$ after induction (Fig. 6). To describe cell growth, $\mathrm{OD}_{600}$ and CDM were determined according to literature [84]. E. coli cell mass was harvested by centrifugation at $18.6 \mathrm{krcf}$ for $15 \mathrm{~min}$ and the supernatant was discarded. The cell pellet was stored at $-20^{\circ} \mathrm{C}$ for later use.

\section{Whole cell preparations}

To generate non-permeabilized cells, the cell suspension $\left(\sim 1 \mathrm{~g}_{C D M} / \mathrm{mL} 50 \mathrm{mM}\right.$ MES buffer) was stored at $4{ }^{\circ} \mathrm{C}$ overnight.

Freeze-thaw treatment: $15 \mathrm{~mL}$ of cell suspension $\left(\sim 1 \mathrm{~g}_{C D M} / \mathrm{mL} 50 \mathrm{mM}\right.$ MES buffer) were put to $-80{ }^{\circ} \mathrm{C}$ in a $50 \mathrm{~mL}$ Falcon tube without any pretreatment. Before usage, cells were thawed at room temperature.

Freeze-dry treatment: The non-permeabilized cell suspension was aliquoted in $1 \mathrm{~mL}$ portions to a 24-well plate, flash frozen with liquid nitrogen and freeze-dried at a temperature of $-40{ }^{\circ} \mathrm{C}$ and a pressure of $\sim 0.2 \mathrm{mbar}$ overnight (Alpha 1-4 LDplus, Martin Christ Gefriertrocknungsanlagen $\mathrm{GmbH}$, Osterode am Harz, DE.

\section{Glucosylglycerol synthesis in whole cell and cell-free systems}

All bioconversions were performed in $100 \mathrm{~mL}$ borosilicate glass bottles equipped with Rotilabo ${ }^{\circledR}$ magnetic stirrer bars $(25 \times 8 \mathrm{~mm}$, Carl Roth $\mathrm{GmbH}$, Karlsruhe, DE). The reaction volume was $50 \mathrm{~mL}$ containing $300 \mathrm{mM}$ sucrose, $1800 \mathrm{mM}$ glycerol, $40 \mathrm{U} / \mathrm{mL}$ sucrose phosphorylase and $50 \mathrm{mM}$ MES buffer. The reaction was performed at $30{ }^{\circ} \mathrm{C}$ (incubation shaker CERTOMAT BS-1, Sartorius, Göttingen, DE) and $300 \mathrm{rpm}$ for $24 \mathrm{~h}$ on a Variomag ${ }^{\circledR}$ Multi-Magnetic Stirrer (Thermo Fisher Scientific Inc. Walthman, MA, USA). The reaction was started by adding the cell suspension. The cell catalyst amount was calculated based on the specific activity of the corresponding cell-free extract. The reaction was stopped by heat treatment $\left(99^{\circ} \mathrm{C}\right.$ for $5-10 \mathrm{~min}$ ) (ThermoMixer $\mathrm{C}$,
E-5048, Eppendorf, Hamburg, DE). The precipitated protein and/or cell debris was removed by centrifugation for $10 \mathrm{~min}$ at $21.1 \mathrm{krcf}$ (Centrifuge Eppendorf 5424 R, Eppendorf, Hamburg, DE) and the supernatant was stored at $-20^{\circ} \mathrm{C}$ until HPLC measurements were performed.

\section{HPLC analysis of reaction compounds}

1-GG, GG, sucrose, glycerol, fructose, and glucose in the reaction mixtures were measured by HPLC, either on a Merck Hitachi L-7100 system (Merck, Darmstadt, DE) or a Shimadzu LC-20AD (Kyōto, JPN), both equipped with an autosampler and RI-detector. The stationary phase was a YMC-Pack Polyamine II $/ \mathrm{S}-5 \mu \mathrm{m} / 12 \mathrm{~nm}$ column $(250 \mathrm{~mm} \times 4.6 \mathrm{~mm})$, additionally, a guard column $(20 \mathrm{~mm} \times 4.0 \mathrm{~mm})$ was installed (both from YMC Co., Ltd., Shimogōy-ku, Kyōto, JPN). Elution was performed isocratically with an acetonitrile-water mixture $(75: 25, \mathrm{v}: \mathrm{v})$ at a flow rate of $1 \mathrm{~mL} /$ min. Measurements were performed at room temperature, the injection volume per sample was set to $20 \mu \mathrm{L}$ and the run time was 30 min. Refractive index detection was used. Peaks were analyzed using the software Chromeleon Chromatography Data System (Thermo Fischer Scientific Inc., Waltham, MA, USA). Calibration was done with standards containing 1-GG, GG, sucrose, glycerol and fructose.

\section{Abbreviations}

GG: 2-O-a-D-glucosyl-sn-glycerol; BaSucP: Sucrose phosphorylase from Bifdobacterium adolescentis; LmSucP: Sucrose phosphorylase from Leuconostoc mesenteroides; CDM: Cell dry mass; 1GG: 1-O-a-D-glucosyl-sn-glycerol; aGlc1-P: a-D-glucose 1-phosphate.

\section{Supplementary Information}

The online version contains supplementary material available at https://doi. org/10.1186/s12934-021-01569-4.

Additional file 1. Continuous coupled activity assay. Figure S1. Plasmids for sucrose phosphorylase expression. (A) PET21: T7 laco promoter is regulated by the repressor protein LaCl. (B) PQE30: T5 laco $_{\text {p }}$ promoter drives transcription, Lacl is lacking. Figure S2. Maximum specific growth rates $\left(\mu_{\max }\right)$. (A) LmSucP_pQE30, (B) LmSucP_pET21, (C) BaSucP_pQE30, (D) BaSucP_pET21. Figure S3. A) Representative SDS PAGE gel for densitometric analysis with the software ImageJ (https://imagej.nih.gov/ij/). The recombinant protein bands of BaSucP $(57.50 \mathrm{kDa})$ and LmSucP $(56.81 \mathrm{kDa})$ are marked with a red arrow. $10 \mu \mathrm{L}$ of stated dilutions from $0.7 \mathrm{OD}$ units were loaded. B) Lane profile plots. Figure S4. SDS PAGE of (A) LmSucP and (B) BaSucP expressed by pQE30 and pET21. The recombinant protein bands of BaSucP (57.50 kDa) and LmSucP (56.81 kDa) are marked with a red arrow. 0.7 OD units were loaded. Table S1. Performance metrics comparison of cell-free extracts containing either BaSucP or LmSucP from pQE30. Figure S5. SDS PAGE gel of LmSuCP shake-flask cultivations at $28^{\circ} \mathrm{C}$ expression temperature. $0.7 \mathrm{OD}$ units were loaded. Figure S6. SDS PAGE gels of fed-batch bioreactor cultivations at (A) $25^{\circ} \mathrm{C}$ and (B) $28^{\circ} \mathrm{C}$ expression temperatures. 


\author{
Acknowledgements \\ The pET21 vectors used were from Prof. T. Desmet (Ghent University).
}

\section{Authors' contributions}

KNS designed the study, performed experiments, analyzed data and wrote the paper. MCP performed and analyzed fed-batch bioreactor cultivations, contributed in writing the "Materials and methods" part and revised the manuscript. GS provided the infrastructure and knowledge for fed-batch bioreactor cultivations and revised the manuscript. BN designed and supervised the study, acquired funding, and wrote the paper. All authors read and approved the final manuscript.

\section{Funding}

This project has received funding from the European Union's Horizon 2020 research and innovation programme under Grant Agreement No 761030 (CARBAFIN).

\section{Availability of data and materials}

The datasets supporting the conclusions of this article are available in the zenodo repository, https://doi.org/10.5281/zenodo.4361383.

\section{Declarations}

\section{Ethics approval and consent to participate}

Not applicable.

\section{Consent for publication}

Not applicable.

\section{Competing interests}

The authors declare that they have no competing interests.

\section{Author details}

${ }^{1}$ Austrian Centre of Industrial Biotechnology (acib), Krenngasse 37, $8010 \mathrm{Graz}$, Austria. ${ }^{2}$ Institute of Biotechnology and Biochemical Engineering, Graz University of Technology, NAWI Graz, Petersgasse 12, 8010 Graz, Austria. ${ }^{3}$ Department of Biotechnology, University of Natural Resources and Life Sciences, Vienna, Muthgasse 18, 1190 Vienna, Austria.

Received: 3 February 2021 Accepted: 22 March 2021 Published online: 07 April 2021

\section{References}

1. Luley-Goedl C, Nidetzky B. Glycosides as compatible solutes: biosynthesis and applications. Nat Prod Rep. 2011;28:875-96.

2. Ferjani A, Mustardy L, Sulpice R, Marin K, Suzuki I, Hagemann M, et al. Glucosylglycerol, a compatible solute, sustains cell division under salt stress. Plant Physiol. 2003;131:1628-37.

3. Klähn S, Steglich C, Hess WR, Hagemann M. Glucosylglycerate: a secondary compatible solute common to marine cyanobacteria from nitrogenpoor environments. Environ Microbiol. 2010;12:83-94.

4. Bianchi G, Gamba A, Limiroli R, Pozzi N, Elster R, Salamini F, et al. The unusual sugar composition in leaves of the resurrection plant Myrothamnus flabellifolia. Physiol Plant. 1993;87:223-6.

5. Farrant JM, Kruger LA. Longevity of dry Myrothamnus flabellifolius in simulated field conditions. J Plant Growth Regul. 2001;35:109-20.

6. Becker J, Wittmann C. Microbial production of extremolytes-high-value active ingredients for nutrition, health care, and well-being. Curr Opin Biotechnol. 2020;65:118-28.

7. Empadinhas N, da Costa MS. Diversity, biological roles and biosynthetic pathways for sugar-glycerate containing compatible solutes in bacteria and archaea. Environ Microbiol. 2011;13:2056-77.

8. Lentzen G, Schwarz T. Extremolytes: natural compounds from extremophiles for versatile applications. Appl Microbiol Biotechnol. 2006;72:623-34.

9. Schagen S, Overhagen S, Bilstein A. New data confirm skin revitalizing and stress protection by Glycoin ${ }^{\circledR}$ natural. Euro Cosmet. 2017;1:24-7.
10. Tan X, Luo Q, Lu X. Biosynthesis, biotechnological production, and applications of glucosylglycerols. Appl Microbiol Biotechnol. 2016;100:6131-9.

11. Takenaka F, Uchiyama H. Synthesis of a-D-glucosylglycerol by a-glucosidase and some of its characteristics. Biosci Biotechnol Biochem. 2000;64:1821-6.

12. Sawangwan T. Glucosylglycerol on performance of prebiotic potential. Funct Food Health Dis. 2015;5:427-36.

13. Roenneke B, Rosenfeldt N, Derya SM, Novak JF, Marin K, Krämer R, et al. Production of the compatible solute a-D-glucosylglycerol by metabolically engineered Corynebacterium glutamicum. Microb Cell Fact. 2018;17:1-14.

14. Tan X, Du W, Lu X. Photosynthetic and extracellular production of glucosylglycerol by genetically engineered and gel-encapsulated cyanobacteria. Appl Microbiol Biotechnol. 2015;99:2147-54.

15. Sauer T, Galinski EA. Bacterial milking: a novel bioprocess for production of compatible solutes. Biotechnol Bioeng. 1998;57:306-13.

16. Kunte H, Lentzen G, Galinski E. Industrial production of the cell protectant ectoine: protection mechanisms, processes, and products. Curr Biotechnol. 2014;3:10-25.

17. Luley-Goedl C, Sawangwan T, Mueller M, Schwarz A, Nidetzky B. Biocatalytic process for production of a-glucosylglycerol using sucrose phosphorylase. Food Technol Biotechnol. 2010;48:276-83.

18. Nihira T, Saito Y, Ohtsubo K, Nakai H, Kitaoka M. 2-O-a-D-glucosylglycerol phosphorylase from Bacillus selenitireducens MLS10 possessing hydrolytic activity on $\beta$-D-glucose 1-phosphate. PLoS ONE. 2014;9:1-10.

19. Touhara KK, Nihira T, Kitaoka M, Nakai H, Fushinobu S. Structural basis for reversible phosphorolysis and hydrolysis reactions of 2-O-aglucosylglycerol phosphorylase. J Biol Chem. 2014;289:18067-75.

20. Franceus J, Decuyper $L$, D'hooghe M, Desmet T. Exploring the sequence diversity in glycoside hydrolase family 13_18 reveals a novel glucosylglycerol phosphorylase. Appl Microbiol Biotechnol. 2018;102:3183-91.

21. Zhang T, Yang J, Tian C, Ren C, Chen P, Men Y, et al. High-yield biosynthesis of glucosylglycerol through coupling phosphorolysis and transglycosylation reactions. J Agric Food Chem. 2020;68:15249-56.

22. Goedl C, Sawangwan T, Mueller M, Schwarz A, Nidetzky B. A high-yielding biocatalytic process for the production of 2-O-(a-D-glucopyranosyl)-snglycerol, a natural osmolyte and useful moisturizing ingredient. Angew Chem Int Ed. 2008:47:10086-9.

23. Wildberger P, Pfeiffer M, Brecker L, Nidetzky B. Diastereoselective synthesis of glycosyl phosphates by using a phosphorylase-phosphatase combination catalyst. Angew Chem Int Ed. 2015;54:15867-71.

24. Franceus $J$. Exploring and engineering the functional diversity of glycoside phosphorylases[dissertation]. Ghent: Ghent University; 2019.

25. Franceus J, Desmet T. Sucrose phosphorylase and related enzymes in glycoside hydrolase family 13: discovery, application and engineering. Int J Mol Sci. 2020;21:2526.

26. Bolivar JM, Luley-Goedl C, Leitner E, Sawangwan T, Nidetzky B. Production of glucosyl glycerol by immobilized sucrose phosphorylase: options for enzyme fixation on a solid support and application in microscale flow format. J Biotechnol. 2017;257:131-8.

27. Zhong C, Nidetzky B. Three-enzyme phosphorylase cascade for integrated production of short-chain cellodextrins. Biotechnol J. 2019:1900349:1-9.

28. Goedl C, Schwarz A, Minani A, Nidetzky B. Recombinant sucrose phosphorylase from Leuconostoc mesenteroides: characterization, kinetic studies of transglucosylation, and application of immobilised enzyme for production of a-d-glucose 1-phosphate. J Biotechnol. 2007;129:77-86.

29. Pimentel MCB, Ferreira MSS. Immobilized sucrose phosphorylase from Leuconostoc mesenteroides. Appl Biochem Biotechnol. 1991;27:37-43.

30. Valikhani D, Bolivar JM, Pfeiffer M, Nidetzky B. Multivalency effects on the immobilization of sucrose phosphorylase in flow microchannels and their use in the development of a high-performance biocatalytic microreactor. ChemCatChem. 2017:9:161-6.

31. De Winter K, Cerdobbel A, Soetaert W, Desmet T. Operational stability of immobilized sucrose phosphorylase: continuous production of a-glucose-1-phosphate at elevated temperatures. Process Biochem. 2011:46:2074-8.

32. De Winter K, Soetaert W, Desmet T. An imprinted cross-linked enzyme aggregate (iCLEA) of sucrose phosphorylase: combining improved stability with altered specificity. Int J Mol Sci. 2012;13:11333-42. 
33. Vandamme EJ, Van Loo J, Machtelinckx L, De Laporte A. Microbial sucrose phosphorylase: fermentation process, properties, and biotechnical applications. Adv Appl Microbiol. 1987;32:163-201.

34. Schwaiger KN, Voit A, Dobiašová H, Luley C, Wiltschi B, Nidetzky B. Plasmid design for tunable two-enzyme co-expression promotes whole-cell production of cellobiose. Biotechnol J. 2020;2000063:1-10.

35. Kitaoka M, Sasaki T, Taniguchi H. Conversion of sucrose into cellobiose using sucrose phosphorylase, xylose isomerase and cellobiose phosphorylase. Denpun Kagaku. 1992;39:281-3.

36. Van Den Broek LAM, Van Boxtel EL, Kievit RP, Verhoef R, Beldman G, Voragen AGJ. Physico-chemical and transglucosylation properties of recombinant sucrose phosphorylase from Bifidobacterium adolescentis DSM20083. Appl Microbiol Biotechnol. 2004;65:219-27.

37. Aerts D, Verhaeghe T, De Mey M, Desmet T, Soetaert W. A constitutive expression system for high-throughput screening. Eng Life Sci. 2011;11:10-9.

38. Koga T, Nakamura K, Shirokane Y, Mizusawa K, Kitao S, Kikuchi M. Purification and some properties of sucrose phosphorylase from Leuconostoc mesenteroides. Agric Biol Chem. 1991;55:1805-10.

39. Kitoa S, Nakano E. Cloning of the sucrose phosphorylase gene from Leuconostoc mesenteroides and its overexpression using a "sleeper" bacteriophage vector. J Ferment. 1992;73:179-84.

40. Kawasaki H, Nakamura N, Ohmori M, Sakai T. Cloning and expression in Escherichia coli of sucrose phosphorylase gene from Leuconostoc mesenteroides No. 165. Biosci Biotechnol Biochem. 1996;60:322-4.

41. Su L, Wang T, Yu L, Wu J. Highly efficient extracellular expression of naturally cytoplasmic Leuconostoc mesenteroides sucrose phosphorylase. J Chem Technol Biotechnol. 2018;93:3135-42.

42. Lee JH, Moon YH, Kim N, Kim YM, Kang HK, Jung JY, et al. Cloning and expression of the sucrose phosphorylase gene from Leuconostoc mesenteroides in Escherichia coli. Biotechnol Lett. 2008:30:749-54.

43. Lee $\mathrm{JH}$, Yoon SH, Nam SH, Moon YH, Moon YY, Kim D. Molecular cloning of a gene encoding the sucrose phosphorylase from Leuconostoc mesenteroides B-1149 and the expression in Escherichia coli. Enzyme Microb Technol. 2006;39:612-20.

44. Sprogøe D, Van Den Broek LAM, Mirza O, Kastrup JS, Voragen AGJ, Gajhede M, et al. Crystal structure of sucrose phosphorylase from Bifidobacterium adolescentis. Biochemistry. 2004;43:1156-62.

45. Verhaeghe T, Diricks M, Aerts D, Soetaert W, Desmet T. Mapping the acceptor site of sucrose phosphorylase from Bifidobacterium adolescentis by alanine scanning. J Mol Catal B Enzym. 2013;96:81-8.

46. Sørensen HP, Mortensen KK. Advanced genetic strategies for recombinant protein expression in Escherichia coli. J Biotechnol. 2005;115:113-28.

47. Balzer S, Kucharova V, Megerle J, Lale R, Brautaset T, Valla S. A comparative analysis of the properties of regulated promoter systems commonly used for recombinant gene expression in Escherichia coli. Microb Cell Fact. 2013:12:1-14.

48. Tegel H, Ottosson J, Hober S. Enhancing the protein production levels in Escherichia coli with a strong promoter. FEBS J. 2011;278:729-39.

49. Brunner M, Bujard $\mathrm{H}$. Promoter recognition and promoter strength in the Escherichia coli system. EMBO J. 1987:6:3139-44.

50. Jahn M, Vorpahl C, Hübschmann T, Harms H, Müller S. Copy number variability of expression plasmids determined by cell sorting and droplet digital PCR. Microb Cell Fact. 2016;15:1-12.

51. Freudenau I, Lutter P, Baier R, Schleef M, Bednarz H, Lara AR, et al. ColE1plasmid production in Escherichia coli: mathematical simulation and experimental validation. Front Bioeng Biotechnol. 2015;3:1-14.

52. Schmidt L, Inselburg J. ColE1 copy number mutants. J Bacteriol. 1982;151:845-54.

53. Tomizawa J, Som T. Control of cole 1 plasmid replication: enhancement of binding of RNA I to the primer transcript by the rom protein. Cell. 1984;38:871-8

54. Manel C. Modulation of ColE1-like plasmid replication for recombinant gene expression. Recent Adv DNA Gene Seq. 2010;4:58-73.

55. Mason AB, He QY, Halbrooks PJ, Everse SJ, Gumerov DR, Kaltashov IA, et al. Differential effect of a His tag at the $\mathrm{N}$ - and C-termini: functional studies with recombinant human serum transferrin. Biochemistry. 2002;41:9448-54
56. Xu CG, Fan XJ, Fu YJ, Liang AH. Effect of location of the His-tag on the production of soluble and functional Buthus martensii Karsch insect toxin. Protein Expr Purif. 2008:59:103-9.

57. Woestenenk EA, Hammarström M, van den Berg S, Härd T, Berglund H. His tag effect on solubility of human proteins produced in Escherichia coli: a comparison between four expression vectors. J Struct Funct Genomics. 2004;5:217-29.

58. Park WJ, You SH, Choi HA, Chu YJ, Kim GJ. Over-expression of recombinant proteins with $\mathrm{N}$-terminal His-tag via subcellular uneven distribution in Escherichia coli. Acta Biochim Biophys Sin (Shanghai). 2015;47:488-95.

59. Gunasekaran K, Tsai CJ, Nussinov R. Analysis of ordered and disordered protein complexes reveals structural features discriminating between stable and unstable monomers. J Mol Biol. 2004;341:1327-41.

60. Rumfeldt JAO, Galvagnion C, Vassall KA, Meiering EM. Conformational stability and folding mechanisms of dimeric proteins. Prog Biophys Mol Biol. 2008;98:61-84.

61. Dougan DA, Mogk A, Bukau B. Protein folding and degradation in bacteria: to degrade or not to degrade? That is the question. Cell Mol Life Sci. 2002;59:1607-16.

62. Seibel J, Jördening H-J, Buchholz K. Glycosylation with activated sugars using glycosyltransferases and transglycosidases. Biocatal Biotransform. 2006;24:311-42.

63. Klimacek M, Sigg A, Nidetzky B. On the donor substrate dependence of group-transfer reactions by hydrolytic enzymes: insight from kinetic analysis of sucrose phosphorylase-catalyzed transglycosylation. Biotechnol Bioeng. 2020;117:2933-43.

64. Goedl C, Nidetzky B. Sucrose phosphorylase harbouring a redesigned, glycosyltransferase-like active site exhibits retaining glucosyl transfer in the absence of a covalent intermediate. ChemBioChem. 2009;10:2333-7.

65. Mueller M, Nidetzky B. Dissecting differential binding of fructose and phosphate as leaving group/nucleophile of glucosyl transfer catalyzed by sucrose phosphorylase. FEBS Lett. 2007;581:3814-8.

66. Mirza O, Skov LK, Sprogøe D, Van Den Broek LAM, Beldman G, Kastrup $J \mathrm{~S}$, et al. Structural rearrangements of sucrose phosphorylase from Bifidobacterium adolescentis during sucrose conversion. J Biol Chem. 2006:281:35576-84.

67. Luley-Goedl C, Nidetzky B. Small-molecule glucosylation by sucrose phosphorylase: structure-activity relationships for acceptor substrates revisited. Carbohydr Res. 2010;345:1492-6.

68. Zimmerman SB, Trach SO. Estimation of macromolecule concentrations and excluded volume effects for the cytoplasm of Escherichia coli. J Mol Biol. 1991;222:599-620.

69. Felix H. Permeabilized cells. Anal Biochem. 1982;120:211-34.

70. Helander IM, Mattila-Sandholm T. Fluorometric assessment of Gramnegative bacterial permeabilization. J Appl Microbiol. 2000;88:213-9.

71. Guha S, Ghimire J, Wu E, Wimley WC. Mechanistic landscape of membrane-permeabilizing peptides. Chem Rev. 2019;119:6040-85.

72. Weyler $C$, Heinzle E. Multistep synthesis of UDP-glucose using tailored, permeabilized cells of E. coli. Appl Biochem Biotechnol. 2015;175:3729-36.

73. Cánovas M, Torroglosa T, Iborra JL. Permeabilization of Escherichia coli cells in the biotransformation of trimethylammonium compounds into L-carnitine. Enzyme Microb Technol. 2005:37:300-8.

74. Gehmlich I, Pohl HD, Knorre WA. Laboratory-scale permeabilization of Escherichia coli cells for recovery of a small recombinant protein-Staphylokinase. Bioprocess Eng. 1997;17:35-8.

75. Israeli E, Giberman E, Kohn A. Membrane malfunctions in freeze-dried Escherichia coli. Cryobiology. 1974;11:473-7.

76. Chen RR. Permeability issues in whole-cell bioprocesses and cellular membrane engineering. Appl Microbiol Biotechnol. 2007;74:730-8.

77. Tufvesson P, Lima-Ramos J, Nordblad M, Woodley JM. Guidelines and cost analysis for catalyst production in biocatalytic processes. Org Process Res Dev. 2011;15:266-74.

78. Toeroek C, Cserjan-Puschmann M, Bayer K, Striedner G. Fed-batch like cultivation in a micro-bioreactor: screening conditions relevant for Escherichia coli based production processes. Springerplus. 2015;4:490. 79. Woodall CA. Electroporation of E. coli. Methods Mol Biol. 2003;235:55-60. 
80. Summers DK, Withers HL. Electrotransfer: direct transfer of bacterial plasmid DNA by electroporataon. Nucleic Acids Res. 1990;18:2192.

81. Eis C, Nidetzky B. Characterization of trehalose phosphorylase from Schizophyllum commune. Biochem J. 1999;341:385-93.

82. Analyze Menu, Gels Submenu. https://imagej.nih.gov/ij/docs/menus/ analyze.html\#gels. Accessed 23 Jan 2021.

83. Mairhofer J, Scharl T, Marisch K, Cserjan-Puschmann M, Striedner G. Comparative transcription profiling and in-depth characterization of plasmid-based and plasmid-free Escherichia coli expression systems under production conditions. Appl Environ Microbiol. 2013;79:3802-12.

84. Cserjan-Puschmann M, Kramer W, Duerrschmid E, Striedner G, Bayer K. Metabolic approaches for the optimisation of recombinant fermentation processes. Appl Microbiol Biotechnol. 1999;53:43-50.
85. Yao D, Fan J, Han R, Xiao J, Li Q, Xu G, et al. Enhancing soluble expression of sucrose phosphorylase in Escherichia coli by molecular chaperones. Protein Expr Purif. 2020;169:105571.

86. Zhang H, Sun X, Li W, Li T, Li S, Kitaoka M. Expression and characterization of recombinant sucrose phosphorylase. Protein J. 2018;37:93-100.

87. Shin MH, Jung MW, Lee JH, Kim MD, Kim KH. Strategies for producing recombinant sucrose phosphorylase originating from Bifidobacterium longum in Escherichia coli JM109. Process Biochem. 2008;43:822-8.

\section{Publisher's Note}

Springer Nature remains neutral with regard to jurisdictional claims in published maps and institutional affiliations.
Ready to submit your research? Choose BMC and benefit from:

- fast, convenient online submission

- thorough peer review by experienced researchers in your field

- rapid publication on acceptance

- support for research data, including large and complex data types

- gold Open Access which fosters wider collaboration and increased citations

- maximum visibility for your research: over 100M website views per year

At BMC, research is always in progress.

Learn more biomedcentral.com/submissions 